\title{
El mundo a la espalda. La vanguardia y el compromiso en el pensamiento sociológico- literario de Francisco Ayala
}

\section{The World on Back. The Avant-garde and Commitment in the Sociological-literary Thought of Francisco Ayala}

\author{
Miguel Ángel García \\ Universidad de Granada \\ garciaga@ugr.es \\ ORCID iD: https://orcid.org/0000-0003-4185-6836
}

\section{RESUMEN}

No se ha resaltado aún el lugar que ocupan las nociones de vanguardia y compromiso en los escritos autobiográficos y los trabajos crítico-literarios de Francisco Ayala, donde a menudo se advierte el sociólogo que hubo en él. La primera etapa de este autor escapa a la fórmula con la que usualmente se resume la trayectoria de la llamada «joven literatura»: de la vanguardia al compromiso. No obstante, como trata de mostrar este artículo, su adhesión al espíritu vanguardista supuso al mismo tiempo contraer un compromiso con las minorías selectas que impulsaban la modernización y la europeización de España. Este compromiso llevaba aparejado un programa estético basado en la autonomía del arte, un presupuesto de larga duración en Ayala que lo insta a separar política y literatura, así como a manifestar sus discrepancias, paradójicamente, con el concepto sartreano de engagement.

Palabras Clave: Francisco Ayala; vanguardia; compromiso; lectura sociológica.

\begin{abstract}
It has not highlighted yet the place of the avant-garde notions and the commitment in the autobiographical writings and literary-critical works of Francisco Ayala, where often the sociologist who was in it warns. The first stage of this author escapes the formula that usually sums up the path of the «young literature»: from the avant-garde to commitment. However, as this paper tries to show, his support to avant-gardist spirit means at the same time that he assumed a commitment with the elites that promoted the modernization and europeanization of Spain. This commitment carried with it an aesthetic program based on the autonomy of art, a budget-length Ayala urging him to separate politics and literature, and to express their differences, paradoxically, with the sartrean notion of engagement.
\end{abstract}

Key words: Francisco Ayala; Avant-garde; Commitment; Sociological reading. 
Más de una vez se ha resumido así la trayectoria ideológica y estética cumplida por los poetas y escritores de los años 20 y 30 en España: de la vanguardia al compromiso, de la pureza a la revolución (Jiménez Millán 1980; Geist 1980; Pérez Bazo 1992; Cano Ballesta 1996; García 2001). Naturalmente, es solo un esquema ideal y pedagógico, una fórmula historiográfica más o menos exacta para referirse a las transformaciones que va experimentando en líneas generales, pero no sin numerosas salvedades y contradicciones internas, la república literaria (Aznar Soler 2010) o el polisistema de nuestras letras (García 2013) desde la llegada de los ismos, y más en concreto desde que Ortega diagnostica la deshumanización del arte nuevo, hasta la Guerra Civil. Al igual que tantos otros, Ayala escapa a ese arco evolutivo - de la pureza a la impureza, de la deshumanización a la rehumanización, de la evasión al compromiso - que la mayor parte de las veces se ha presentado, simplificando en exceso, como una línea unidireccional y lógica, determinada por la presión de las circunstancias sociales, políticas e históricas que marcan la vida del país entre la Dictadura de Primo de Rivera, la proclamación de la Segunda República y la sublevación militar. Ni el vanguardismo español desconoció el compromiso ideológico (García 2016a) ni la llamada «literatura de avanzada» o las vanguardias políticas dejaron de aprovechar la lección formal de las vanguardias estéticas (Salaün 1998a y 1998b). Ayala no compromete su obra en los años 30, como ocurre con la punta de lanza de «la joven literatura» y con otros representantes de «generaciones» anteriores y de la siguiente, lo cual no quiere decir que su compromiso intelectual y político con la República no fuera inequívoco. Mi intención es poner de relieve el significado cultural y social que asigna a la vanguardia en sus escritos autobiográficos, así como en sus trabajos crítico-literarios, donde asoma con frecuencia el sociólogo que hubo en él ${ }^{1}, \mathrm{y}$ mostrar hasta qué punto el compromiso con la ideología liberal, modernizadora y europeizante, no solo determina su lectura del vanguardismo en el que se vio envuelto durante la juventud sino también su alejamiento del concepto estricto de engagement teorizado por Sartre.

\section{LA GENEALOGÍA AYALIANA DE LA VANGUARDIA Y EL RAMONISMO}

Romera Castillo (1992: 75-76) ha llamado la atención sobre cómo Recuerdos y olvidos constituye en buena medida una autobiografía literaria en la que Ayala da cuenta, entre otras cosas, de su incorporación a la vanguardia como escritor incipiente. Tras el traslado de Granada a Madrid, es su paisano Melchor

${ }^{1}$ Existe a la vez una estrecha relación, como es lógico, entre su discurso creador y su discurso crítico (Chicharro 1992: 254). Viñas Piquer (2004: 48) descubre siempre unas mismas maniobras en el Ayala teórico y crítico literario: «abstracción teórica, concreción crítica, extensión comparativa y refuerzo histórico-sociológico». 
Fernández Almagro quien le facilita el acceso inicial al «paraíso de la letra impresa», la posibilidad de publicar sus primeros artículos (Ayala 2006: 122). Pronto acude a la tertulia de Pombo, habiendo ya leído a Gómez de la Serna e incluso habiéndolo visto lanzar una proclama desde un trapecio del Circo Price. No deja de señalar que el tono de esa tertulia era, a veces, «muy forzadamente eutrapélico», con algunas bromas crueles, y recuerda que se ocupó de ella a petición del pintor Gabriel García Maroto, editor del Almanaque de las artes y las letras para 1928 (p. 130) ${ }^{2}$. No solo dibuja en este Almanaque el ambiente de la tertulia de Pombo, en efecto; también el de la Revista de Occidente, adonde es llevado y presentado a Ortega por Benjamín Jarnés (Ayala 1980: 1472-1473, 1985: 355-356 y 2006: 137-138), así como el de La Gaceta Literaria y muy probablemente el de algunas otras cuya descripción aparece sin firma (Soria Olmedo 2006: 203-205). El contacto con esas tres conocidas tertulias marca la inmersión progresiva del joven Ayala en los círculos de la vanguardia española. Por lo que se refiere a la tertulia de la Revista de Occidente, la galería de retratos «arbitrarios», hechos «en esquema o en gran plano cinematográfico»y distribuidos por salas «también arbitrariamente» (Ayala 1928a: 1317), comienza por Ortega, como es lógico, a quien presenta como «capitán, sobre cubierta». La sala de gobierno está presidida por Fernando Vela, «espíritu germanizado» de eficacia máxima, a quien acompañan García Morente, «rizoso, andaluz y profesor de Filosofía», y José Díaz Fernández, «el terror de las imprentas» (p. 1318). Siguen la sala de profesores y científicos (Zubiri, Américo Castro, Fernando de los Ríos, entre otros) y la sala médica, en la que destaca Marañón: «Qué tradición, los médicos liberales de España» (p. 1319). Más interés tiene para nosotros la sala de «la joven literatura», con Antonio Marichalar, Antonio Espina, Jarnés, Ramón de Basterra y Gómez de la Serna, la voz que lo llena todo y que tiene días fijos para ir: "Y esos días se convierten en fiesta, adornados con lazos greguerizantes» (p. 1319).

Si la tertulia de la Revista de Occidente aparece caracterizada por su paisaje intelectual y «de altura urbana», la de La Gaceta Literaria, revista que

${ }^{2}$ En otro lugar precisa que fue Fernández Almagro quien lo introdujo, recién publicado su primer libro, Tragicomedia de un hombre sin espiritu (1925), y provisto de esta credencial, en la tertulia de Pombo. Lo que presenció allí, y que relató en el Almanaque de García Maroto, le desagradó demasiado para que jamás deseara volver. Añade que sus posteriores encuentros con Ramón Gómez de la Serna fueron escasos y nunca muy directos: «Sin duda alguna, debió de guardarme siempre una temerosa animadversión, él tan aprensivo, tras de mi reportaje sobre su tertulia de Pombo; y yo por mi lado sentía hacia su entidad humana un fuerte rechazo» (Ayala 1992a: 1372). Puntualiza, aun así, que «mi admiración hacia su personalidad literaria era muy grande». No todos los retratos que realiza Ayala -indica Lapesa (1988: 339) - son «loores de claros varones», y el de «Ramón» resulta en efecto más bien desabrido y áspero, como también hace notar Caballero Bonald (2006: 265-266) al tiempo que señala cómo los «modales literarios» de Gómez de la Serna (en especial las greguerías) impregnan la obra vanguardista del granadino. 
define como «Film de actualidades. Noticiario», reúne ya exclusivamente a los escritores jóvenes, con su director Giménez Caballero a la cabeza y el recuerdo de su secretario, Guillermo de Torre, que ya para entonces ha marchado a Buenos Aires. A Jarnés y Espina, los dos concurrentes a la tertulia de la Revista de Occidente con los que más estrecha relación tuvo Ayala (2006: 142), se suman en este otro espacio César M. Arconada, Fernández Almagro, García Maroto y Miguel Pérez Ferrero, quien (de nuevo se recurre a una perspectiva cinematográfica) «corta — de dentro a fuera - el plano del ecrán» (1928a: 1321) ${ }^{3}$. Marichalar, Espina, Jarnés, Arconada y Pérez Ferrero también se dejan ver en la tertulia de Pombo en honor a la excepcionalidad literaria de Gómez de la Serna y a «su significación — punto inicial— en el arte nuevo» (p. 1323). Pero Ayala invita a discriminar entre lo que «Ramón» tiene de precursor de la modernidad y lo que viene a ser pura escoria, "pura impureza», pues al fin y al cabo el signo más influyente en él es el siglo XIX; su desgana del cine, pese a «la maravilla de Cinelandia, escrita de espaldas al ecrán», su miedo al automóvil, a la velocidad, son síntomas de una raíz decimonónica: «Completados por esa actitud tan erguida y directora - de hombre del pescante - que adopta en la tertulia de Pombo» (p. 1322). Este retrato bifronte de un Gómez de la Serna que señala el camino a la nueva literatura, aunque en buena parte sigue anclado en el siglo XIX, tiene su importancia porque revela al escritor plenamente vanguardista y sin concesiones que es Ayala a finales de los años 20. Hasta el punto de no admitir ningún tipo de «regresión», de defender el arte nuevo de sus enemigos, como deja bien claro al reseñar Ejercicios, de Jarnés, en La Gaceta Literaria, no sin precisar que este novelista de los «Nova novorum» encarna la norma estética correspondiente al «espíritu de vanguardia», forjada en las trincheras, «en las avanzadas» (Ayala 1927a: 510). La conjunción del «ramonismo» con la vanguardia, dirá en Recuerdos y olvidos, se produjo por su nueva manera de ver las cosas, «una óptica a través de la cual la realidad se revelaba bajo aspectos insospechados antes» (2006: 132). «Ramón» es un hombre solo frente a un mundo lleno de cosas sin catalogar, algunas de la más reciente manufactura, y lo que hace es colgar a cada cosa una «etiqueta nominativa», una greguería, encontrándole, con su ojo único y clarividente, «el flanco inesperado de la definitiva rendición» (Ayala 1927b: 485). Lo vuelve a poner de manifiesto en su reseña, para la Revista de Occidente, de Poemas interdictos, del mexicano Maples Arce: sustancialmente, el arte nuevo consiste en una «nueva manera de ver», y la enorme importancia literaria de Gómez de

${ }^{3}$ No puede olvidarse la atención que Ayala presta al cine, como testimonian su Indagación del cinema (1929) y la utilización de recursos del séptimo arte en sus prosas vanguardistas (García Montero 1992, 1995 y 2006; Navarro Durán 2006). 
la Serna, «su gran papel de precursor», no es otra que la de haber descubierto un punto de mira inédito (1927c: 457) .

Muchos años después se preguntará por la actualidad de Gómez de la Serna, resaltando que su influencia literaria ha sido profunda y universal, aunque su obra no ha trascendido al gran público al tener ese carácter minoritario que Ortega descubrió en el arte nuevo. Ayala se hace eco de la apodíctica sentencia orteguiana «Dondequiera que las jóvenes musas se presentan, la masa las cocea», que no considera errónea, porque «el coceo a que impiadosamente alude era cosa de general experiencia por entonces» entre los filisteos cuya sensibilidad estaba educada en unos patrones estéticos distintos a los nuevos (1992b: 637). Nuestro autor asumió desde el comienzo el programa cultural e ideológico minoritario de Ortega y lo justificó en diversas ocasiones, como habremos de ver. Lo que me interesa destacar en este momento es que sumerge a Gómez de la Serna en el elitismo de la vanguardia, lamentando la imagen pintoresca en que se han detenido las miradas sin penetrar, no ya en su creación literaria, sino incluso en unas «actuaciones histriónicas que, lejos de ser frívolas, albergaban un significado profundo, más allá de su intención obvia de impresionar y desafiar las pautas convencionales de la burguesía llana» (p. 638)5. Se refiere, claro, a la voluntad de épater le bourgeois, que ya había sido ensayada - continúa diciendo - por generaciones sucesivas desde el Romanticismo hasta la del 98, pero las actuaciones de «Ramón» y en general de las vanguardias implicaban a su juicio una «subversión más seria»" ${ }^{6}$. No debe pensarse, con todo, que su militancia vanguardista lleve al granadino a sumarse en los años 20 a la provocación antiburguesa de ciertos ismos europeos; antes bien, participa del control institucional y los filtros constructivos a los que la burguesía liberal reformista, comenzando por el Ortega que lee el arte nuevo, somete la vanguardia en España (García 2011). Cuando se ocupa del «poeta y profesor» Salinas, afirma que la nueva poesía o la nueva literatura asumía «apariencias

${ }^{4}$ En entrevista con García Galiano, reconoce influjos ramonianos - «que, por otro lado, eran fruto de la época, generacionales»-sobre los relatos de El boxeador y un ángel (1929) y Cazador en el alba (1930). Gómez de la Serna, reitera aquí, «nos ofrecía una nueva manera de ver las cosas» (Ayala 1996a: 1632). Mientras que para la mayoría la mirada infantil se deseca, el artista grande que fue él la conservó y la logró formular en estructuras objetivas mediante las greguerías: «Como tuvo la coyuntura histórica de su parte para propiciar esa visión, su fórmula adquirió trascendencia cultural» (p. 1632).

${ }^{5}$ Cuando subraya en otro momento su «personalidad de innovador originalísimo», ve en estas actuaciones histriónicas «la expresión más audaz, brillante y versátil del espíritu de la vanguardia, que transformó el panorama cultural del mundo con su revolución de las sensibilidades estéticas y de las formas artísticas» (Ayala 1988a: 1493).

6 Tras aclarar que la perspectiva sociológica y las reflexiones sobre problemas estrictamente literarios se dan la mano en el Ayala crítico, Senabre (2006: 365) recuerda cómo marca un corte entre Galdós, cuya novela se dirige a un público de clase media, y el 98 , que supone el divorcio entre la clase burguesa y la república de las letras. 
burguesas», lejos de cualquier malditismo residual, «y si se despegaba de esta grisura era para inclinarse hacia el atuendo deportivo» (1985: 367). No olvidemos que uno de los signos del arte nuevo diagnosticado por Ortega es su sentido lúdico, deportivo, intrascendente, juvenil. La reseña que Ayala hace en 1928 de Urbe, de Arconada, en La Gaceta Literaria es inequívoca a este respecto. No solo se refiere a que el «módulo ágil, enérgico y alegre sobre que gravita nuestro tiempo» es el hombre de veinte años - «Pocas veces como ahora, "el joven" ha sido el centro de la vida social»- sino que también comenta cómo este poeta «se lo juega todo al deporte, sin darle a cada salto más trascendencia — ni menos_ de la que tiene en realidad» (1928b: 547).

Ese mismo año publica en la revista Síntesis, de Buenos Aires, un artículo sobre «la joven literatura española» en el que comienza aludiendo al reciente viaje de Marinetti a España, que a su juicio ha tenido, si no una concreta eficacia de orden político o literario, o político-literario, sí el valor de una afirmación. Como vemos, separa desde el inicio literatura y política: la llegada del futurista italiano afirma cuestiones literarias, no de política literaria o de política a secas, como sin duda ocurrió para un Giménez Caballero cada vez más próximo al fascismo. La presencia de Marinetti permite contemplar la distancia recorrida por el vanguardismo español, el proceso de la «nueva sensibilidad en España», que adquiere caracteres peculiares desde que Gómez de la Serna dejó de ser un luchador solitario — «formidable Sansón entre los filisteos»- y desde que Guillermo de Torre lanzó sus Literaturas europeas de vanguardia «haciendo prosperar esta palabra entre nosotros» (1928c: 576). Ayala deja clara su incorporación al proyecto constructivo y liberal hacia el que es encauzada la vanguardia en España, lejos de cualquier subversión antiburguesa, cuando señala a continuación que las condiciones en que «nuestra joven literatura» se ha formado, frente al «concepto combativo, duro y de primeros planos» que encarna Marinetti y «sin la correspondencia social - negativa primero, y luego positiva - que obtuvieron el futurismo y, en general, todas las vanguardias europeas», la han conducido a «posiciones de suma exigencia intelectual» hasta dotarla de una «fisonomía propia» (p. 577). La vanguardia española, y más en concreto «la joven literatura», coadyuva, en efecto, a la tarea reformista de la minorías modernizadoras y liberales, al margen de toda provocación de gran calado y de cualquier hostilidad ideológica o «política» hacia la clase burguesa. De aquí su signo diferencial, su fisonomía propia, con respecto a las vanguardias europeas. Volverá a plantearlo nuestro autor tiempo después, con meridiana claridad, al asegurar que el primer tercio del siglo XX presenció la combinada acción de «dos gigantescas generaciones», la del 98 y la del 14, por prestar vitalidad y coherencia a la anhelada nación española que Ortega calificara de «invertebrada» y por incorporarla, «siquiera en la esfera de la alta cultura», al cuadro de las naciones europeas (1997a: 1216). Más aún: a esas dos previas promociones nacionalistas vino a sumarse «una nueva y no menos brillante generación, la conocida como "vanguardista"», en la que, no hace 
falta decirlo, Ayala se inscribe a sí mismo ${ }^{7}$. Si la generación del 98 - concluye - fue «patéticamente nacionalista» y la generación de 1914 «seriamente nacionalista», la de la vanguardia estaba superando a su modo el nacionalismo para situarse culturalmente por encima de las fronteras en un momento en que España, antes de que la guerra diera al traste con este proyecto, empezaba a conciliarse por fin con la «modernidad europea» (p. 1218). Modernidad europeizante y vanguardia van ligadas en la lectura sociológica ayaliana, que como estamos viendo sitúa este episodio literario y artístico en el contexto social, político e histórico de la España del primer tercio del siglo XX, «la época de nuestro último esplendor cultural» (Ayala 1997b: 1076).

Ramón Gómez de la Serna es considerado por Ayala adalid de los escritores jóvenes pertenecientes a una generación posterior a la suya, un «adelantado de la vanguardia» (1992a: 1369). El granadino dibuja así la genealogía inmediata de la generación vanguardista o «la joven literatura» a la que pertenece. No sin añadir que, si los partidarios de la vanguardia mostraban una resuelta propensión a actuar colectivamente, agrupándose en movimientos que lanzaban manifiestos y revistas efímeras, Gómez de la Serna se empeñaba, por el contrario, en afirmar su «individual originalidad» (de hecho, deja constancia de cómo Fernández Almagro se refirió con acierto a «la generación unipersonal» de Gómez de la Serna). La joven literatura, efectivamente, también va a dar por concluida la época de los manifiestos y algaradas. Donde sobre todo palpita la originalidad de Gómez de la Serna es, a juicio de Ayala, en la feliz fórmula de las greguerías, que dejó una «huella inconfundible» en la obra de los jóvenes poetas y prosistas. Incluido él, que se sintió atraído no solo por lo que «Ramón» escribía y publicaba sino también por una serie de actuaciones vanguardistas (la aludida conferencia en el trapecio o montado en un elefante) que constituían algo inseparable de su escritura. Estas actuaciones representaban, nos dice ahora, una «ruptura radical» frente a la actitud seria de las generaciones precedentes, como la del 98. A su entender, la actividad vital de Gómez de la Serna, como la de la vanguardia, respondía por completo a un espíritu lúdico, a una revolución puramente estética y por lo tanto intrascendente, en el sentido preciso que dio Ortega a este término para definir el arte nuevo «en aquel su controvertido y sin duda objetable ensayo sobre La deshumanización del arte» (p. 1371). Poco a poco iremos viendo que, pese a estas palabras, suscribe el proyecto cultural, filosófico y político de Ortega, y naturalmente su diagnóstico del arte nuevo. Pensemos en cómo justifica la polémica imagen del «coceo» de la masa ante las jóvenes musas. Por ahora, me importa señalar que Ayala proyecta sobre el Gómez de la Serna adelantado de la vanguardia, de la

${ }^{7}$ Recordemos que, para el Ayala de Tratado de sociología, la generación constituye la «unidad histórico-sociológica elemental» y un concepto de precisión científica, como muestra a partir de las generaciones literarias y artísticas (2008: 395-409). Para sus objeciones a la teoría orteguiana: Soldevila Durante (1992: 42-44) y Ribes Leiva (2007: 190-202). 
vanguardia tal y como el granadino la entiende, dos rasgos que el filósofo asigna al arte nuevo: su carácter minoritario, como hemos visto más arriba, y su sentido lúdico. No por ello deja de matizar a continuación que aquel «espectador meditativo» miraba a «Ramón» con la divertida simpatía que puede suscitar un «monstruo de feria». Ese espectador dio razón del fenómeno de la vanguardia con la misma actitud de «distancia intelectual» con la que había elaborado «su programa» de las Meditaciones del Quijote (1914); un programa reflexivo y filosófico, en efecto, pero también político. Como apunta a renglón seguido, Ortega no estaba menos preocupado por el problema de España que los escritores del 98 y no cesó en momento alguno de bregar con él, llevándolo incluso al «terreno de la política práctica» (p. 1371) ${ }^{8}$. Por el contrario, Gómez de la Serna fue por naturaleza ajeno a la política, pese a sus «confusas veleidades anarquistas» de primera hora. Si bien aprueba la actitud vital y artística, lúdica e intrascendente de «Ramón», no duda en considerar «monstruosa» la razón que daba en su exilio bonaerense para preferir las dictaduras a las democracias: «en tiempos de censura oficial los periódicos no tienen mucho material informativo publicable y así disponen de mayor espacio para sus greguerías»» (1996a: 1637). Con todo, puntualiza a continuación que ha de admirarse al «monstruo cuya anomalía segrega sustancias que tanto enriquecen a la humanidad» (p. 1638). Ayala da a la política lo que es de la política y a la estética lo que es de la estética, sin confundirlas jamás. La grandeza de «Ramón», concluye, es un tanto repulsiva, pero es la grandeza de un genio, de cuya pluma brota irrestañable e indiscriminadamente la expresión originalísima de la realidad según él la veía, una producción inusitada sin ningún tipo de control crítico: «Publicaba incontinentemente greguerías, verdaderas joyas de la poesía, mezcladas con auténticas patochadas y chistes de calendario. Pura profusión y pura incapacidad de discernir» (p. 1638).

\section{Del Ultraísmo a «LA JOVEn Literatura»}

Más allá de estos juicios en que se da una de cal y otra de arena, Ayala recuerda que la figura sin par de Ramón Gómez de la Serna «dominaba, señera, el paisaje de la nueva literatura, junto a los movimientos de vanguardia, creacionismo y ultraísmo» cuando él se incorporó con entusiasmo, tras alguna breve pausa desorientada, a la vanguardia (Ayala 1990: 43). Llegado a Madrid con dieciséis años de edad, aún no había tenido noticia de sus movimientos: «la vanguardia era terra incognita» (2006: 133). Por aquellas fechas, precisa,

${ }^{8}$ El mismo Ayala bregó después con el problema de España, oponiéndose, desde planteamientos sociológicos e historicistas, a las concepciones esencialistas de Claudio Sánchez Albornoz y Américo Castro, quienes en esto coinciden con el 98 (Ribes Leiva 2007: 202221). 
el ultraísmo estaba ya en su fase de liquidación, sin haber dejado obra importante, pero habiendo cumplido la tarea de «limpiar la atmósfera literaria al despejarla de los residuos modernistas desacreditados» (p. 133). Esta lectura del ultraísmo coincide plenamente con la que hacen desde muy pronto otros representantes de la «joven literatura» como Dámaso Alonso y Gerardo Diego. Junto al reconocimiento de lo que supuso para él la presencia de «Ramón», le otorga un lugar en la reconstrucción de su genealogía vanguardista a Rafael Cansinos Assens, el «extraño patriarca» del movimiento ultraísta, a cuya tertulia acude entrando en contacto con los hermanos Rivas Panedas, César A. Comet, Pedro Garfias o César González-Ruano (ni Borges ni Guillermo de Torre, aclara, se encontraban entonces en Madrid). No obstante, al igual que ocurre con Gómez de la Serna, a quien sitúa en buena parte en el siglo XIX, muestra su sorpresa por el papel que asumió Cansinos en la promoción del ultraísmo: «Sorprende, digo, porque su propio estilo y el sentido todo de su obra personal es por completo ajeno a la estética promulgada por aquella subversión literaria» (p. 134). Es otro ejemplo del Ayala observante de la norma vanguardista. Al ultraísmo también le adjudica, como a «Ramón», un carácter subversivo, que nuevamente reduce al aspecto cultural o literario, sin trasladarlo nunca al orden político o ideológico. Más adelante, comentando La novela de un literato, define a Cansinos como «un escritor de talla más que mediana» que no merece el olvido en que luego cayó (p. 628). Nos cuenta así, en otra ocasión, cómo oyó a Borges expresar reiterada y abiertamente su admiración por este escritor, «infravalorado sin duda por nosotros», aunque apuntando que se ha difundido «una interpretación maliciosa de su declarado aprecio por quien consideró un maestro, según la cual no sería ello sino mezquina coartada para rebajar u omitir al resto de los escritores peninsulares» (1996b: 823).

La entrevista que Ayala realiza a Guillermo de Torre antes de su marcha a Buenos Aires también contiene sustanciosos juicios sobre el ultraísmo y sobre la deriva racionalista y constructiva que ha ido adquiriendo la vanguardia española con «la joven literatura». Nada más iniciarla, dice adivinar el emblema futurista de la máquina en el ritmo, el pulso y hasta el color de la prosa de este antiguo ultraísta, en su estilo terso, metálico y compacto. En opinión de Torre, son «resabios del momento primero, cuando comulgaba con el futurismo» (Ayala 1927d: 505). No es que haya abominado del maquinismo, matiza a continuación, pero ya no es su idólatra. Ahora acepta esos elementos, pero con serenidad, asimilándolos en su sensibilidad como cualquier otro elemento del día. Ayala le pregunta qué piensa hoy del futurismo. La respuesta de Torre ilustra a la perfección la trayectoria que ha recorrido «la joven literatura» con respecto a la vanguardia inicial: "Que es todo programa, intención. No ha realizado una sola obra. Lo mejor de Marinetti son sus manifiestos» (p. 505). Incluso, sus manifiestos de propaganda están redactados en una desordenada y antipática forma de proclama política: «Ese aire político de anteponer el grupo a la personalidad y la doctrina a la obra, hace imposible — a la larga - el fu- 
turismo» (p. 505). El punto de vista no puede ser más coincidente con el de Ayala (recordemos cómo interpreta en 1928 el viaje de Marinetti a España). También pregunta a Torre por el movimiento del que fue el «máximo campeón» en España, el ultraísmo. El autor de Literaturas europeas de vanguardia es taxativo: el ultraísmo está disuelto como grupo. Puntualiza, además, que no era sino un grupo circunstancial, sin íntima cohesión, formado para la lucha: «Ha pasado su momento, una vez cumplido su papel. En cuanto a su eficacia - romper con el pasado: no con el pasado global y abstracto, sino con el pasado más inmediato-, es innegable» (p. 505). Torre no deja de señalar que los que se creían más inmunes al «bacilo» ultraísta son los más afectados por él. Reivindica, pues, las conquistas que pasan de este movimiento a la literatura posterior. Pero cree, al mismo tiempo, que la denominación de «ultraísta» debe desaparecer, pues carece de contenido, a pesar de que «nuestro gran Ortega y Gasset» haya visto en ella uno de los nombres más felices para designar el nuevo estado de espíritu: «Debe ser sustituida por "vanguardista", más amplia, y generalmente aceptada. Con correspondencia en todos los idiomas» (p. 505). También tienen interés otras observaciones de Torre. A la pregunta que le hace Ayala sobre si mantiene su fe en «todos esos movimientos de posguerra, de los que usted ha sido el mejor exégeta y codificador», responde que esos movimientos no marcan el final de una época sino el principio de otra. Por lo demás, cree que hasta 1914 se ha vivido del siglo XIX y no han comenzado los valores del XX: el cubismo pictórico, Proust en la novela, Apollinaire en la poesía y, «entre los nuestros, yo solo señalaría como genuinos coetáneos y directores a Ortega y a Gómez de la Serna — focos atencionales de la juventud—》 (pp. 506-507).

Al igual que Torre, Ayala ha sido ganado por el programa constructivo orteguiano, reformista y minoritario, aunque esto no supone para ninguno de los dos renunciar al espíritu juvenil de la vanguardia. En el ya citado artículo sobre «la joven literatura española» señala que Marinetti se ha referido en sus conferencias madrileñas al movimiento ultraísta. La invocación al ultraísmo es inexcusable - escribe - «siempre que se quiera aludir a las primeras manifestaciones de la nueva literatura en España», pero inadecuada «si se habla pensando en la actualidad estricta» (1928c: 577). La lucha ultraísta pertenece, pues, al ayer. Coincidiendo con Torre, afirma que el ultraísmo, que sirvió de base a una liquidación total del pasado, se declaró acabado hace unos años: «Su eficacia - de actitud y de dogma estético — fue considerable, y dentro de nuestra historia literaria desempeña un papel destacado en la iniciación de una época. Papel que difícilmente podrá serle discutido» (p. 577). Instalado en el concepto de arte nuevo, tal y como lo interpreta Ortega de acuerdo con sus intereses de vertebración y europeización de España, con la lucha de unas élites que buscan la consolidación hegemónica de la ideología liberal, Ayala da por cancelada muy pronto, en consonancia con la plana mayor de «la joven literatura», la subversión vanguardista, tanto en arte como desde luego en política. Pasado 
el tiempo, reconocerá que las primeras tendencias vanguardistas hispánicas trajeron una ruptura, pero no creaciones importantes. De aquella primera vanguardia, del creacionismo y del movimiento ultraísta, no quedó apenas, a su juicio, obra apreciable: «Del ultraísmo el único gran escritor luego destacado fue Borges, argentino; y antes, en el creacionismo, el chileno Huidobro, con Gerardo Diego y Larrea» (1992c: 1593).

\section{EL PROGRAMA ORTEGUIANO}

Vistas así las cosas, lo de menos son las reservas y los matices que Ayala pondrá andando el tiempo al Ortega de La deshumanización del arte, uno de los «focos atencionales de la juventud», como hemos visto que lo considera Guillermo de Torre, quizás el foco fundamental si atendemos a la repercusión sobre los jóvenes de la lectura no solo estética, sino también ideológica y política, que el filósofo in partibus infidelium hizo de la vanguardia y que incluso es una lectura sociológica, porque se recordará cómo emplea también este punto de vista para caracterizar el arte nuevo. Es cierto que, en una entrevista de 1971 recogida en Confrontaciones, declara que no hubo nunca una verdadera influencia de las teorías orteguianas sobre los intentos narrativos o novelescos de los prosistas de la vanguardia ${ }^{9}$. Ortega, continúa diciendo, era un espíritu despierto y curioso de toda novedad, por lo que fijó su interés en cuanto hacían los jóvenes, tanto en literatura como en las demás artes, y acuñó para explicarlo «ese afortunadamente desafortunado término de deshumanización», que ante todo era un diagnóstico (Ayala 1972: 139). Tras ampararse en su devoción y admiración por el filósofo, confiesa estar persuadido de que carecía de una verdadera sensibilidad artística, de que la nueva estética de entonces le parecía cosa curiosa, simpática, pero no le hacía vibrar hasta sintonizar con ella. Por eso el tono de su teorización le parece «condescendiente». Muy probablemente así fue, pero importa reparar en que, a pesar de que $L a$ deshumanización del arte suponía un diagnóstico y no una preceptiva, «la joven literatura» lo tuvo muy en cuenta en sus producciones concretas y lo convirtió

${ }^{9}$ La palabra de Ortega, dirá en otra ocasión, era escuchada como un oráculo: «Raras veces las opiniones de un intelectual han tenido una eficacia inmediata tan decisiva y tan voluminosa como la que tuvieron las suyas, por quince o veinte años, en España» (Ayala 1972: 189). Cáceres Sánchez (1992: 240) sostiene, con razón, que la práctica narrativa de Ayala no es la respuesta del militante orteguiano ante las consignas del maestro, sino que la deshumanización constituyó un fenómeno histórico, de época, y es aquí donde se puede situar la presencia de Ortega en los inicios literarios del autor, y no en el terreno resbaladizo de las influencias. En esta misma línea, Senabre (2001: 20) aprecia en Ayala un deseo de eludir la gravitación orteguiana en la prosa ensayística. Para Sobejano (2012: 22), en fin, supo asimilar lo más admirable de Ortega: la claridad y la implantación de la teoría en la vida. 
en una suerte de suelo nutricio. El mismo Ayala apunta que Rosa Chacel decidió, a raíz de la teoría orteguiana, escribir novelas deshumanizadas, «siguiendo las pautas establecidas por el maestro, propósito anunciado pero, hasta ahora, no cumplido» (p. 140). En realidad, no ya Chacel sino todos los prosistas de la colección «Nova Novorum» y su entorno escribieron novelas más o menos deshumanizadas que, si no seguían al pie de la letra las pautas establecidas por el maestro en La deshumanización del arte o en Ideas sobre la novela, desde luego tampoco las ignoraban. Chacel recuerda que «fuimos muy pocos» los jóvenes prosistas de vanguardia (Jarnés el más importante) y que «Ayala era muy bueno en un principio, pero ese desertó», no solo cambió sino que también «cambió diciendo que aquello nuestro era un disparate, que aquello no conducía a nada» (Glenn 1990: 11). Naturalmente, se refiere al examen de conciencia que constituye el tan traído y llevado prólogo a La cabeza del cordero (1949), del que me ocuparé más abajo ${ }^{10}$.

Que los jóvenes prosistas, incluido Ayala, dialogan con el concepto de deshumanización y las teorías orteguianas sobre la novela es algo fácilmente comprobable en las reseñas de las novedades narrativas que va haciendo a finales de los años 20, tanto en La Gaceta Literaria como en la Revista de Occidente (Mora Sánchez 1992; Pulido Tirado 1992; Soria Olmedo 2006: 198201, 208-209). Por ejemplo, de El profesor inútil, de Jarnés, dice que es un libro casi desnudo de acción, poco objetivo, de orientación lírica, de base psicológica, «lo que, en relación con las notas de Ortega, es de una gran importancia sintomática», o bien un libro con «frecuente persecución de la imagen (¿Novela? ¿Poema?)» (1927e: 482). A raíz de la publicación de Pájaro pinto, de Espina, entrevista a este autor, quien destaca cómo la novela actual ha sustituido varios elementos importantes de la anterior, como la descripción lógica y racional por una proyección imaginista y más libre: «Otro carácter de la novela actual — común a todo el arte contemporáneo- es la deshumanización, señalada por Ortega. No importa tanto el documento humano como las motivaciones líricas y burlescas —deshumanizadas y neutras — que puede originar» (1927f: 489) ${ }^{11}$. Al reseñar Paula y Paulita, también de Jarnés, comienza por

${ }^{10}$ Puede verse, para las distintas formas que Ayala y Chacel tienen de eludir el exilio, el trabajo de Matamoro (2009), quien plantea cómo en estos dos autores el episodio «aproximadamente vanguardista» deja escasa huella - lo cual resulta inexacto sobre todo en Chacel, que siempre se mantuvo fiel al proyecto orteguiano (García 2016b), y de aquí la crítica a la «deserción» de Ayala-, cómo sus títulos decisorios y canónicos son obra de exilado y cómo, al transterrarse, según díría Gaos, llevan a cabo una suerte de revisión de su historia literaria (p. 73).

11 Ayala se encarga de hacer en el citado Almanaque de las artes y las letras para 1928 el balance de lo que ha supuesto 1927 y el pronóstico de lo que se espera del año venidero. Para la sección de literatura española consulta a Giménez Caballero, quien resalta la aparición de La Gaceta Literaria y de revistas de provincias como Verso y Prosa, la publicación de Canciones, de Lorca, Pájaro pinto, de Espina, Ejercicios, de Jarnés, y desde luego el 
definirla como una «novela de tipo poemático» (repárese en la pregunta que ya se hace sobre El profesor inútil: «¿Novela? ¿Poema?») y yuxtapone, como Ortega, el concepto de deshumanización al de pureza: este prosista, buen conocedor de los límites del arte, se cuida de no lastrar sus obras con elementos de otra intención $\mathrm{y}$, en tal sentido, «realiza la única posibilidad que existe de arte puro, desentendiéndose por modo pasmoso de cuanto sea ajeno a su actividad creadora» (1929: 554) $)^{12}$. Dos años antes, cuando reseña Margarita de niebla, del mexicano Jaime Torres Bodet, Ayala se felicita de que las «futuridades» contenidas en la «manera» que Jarnés ha incorporado a El profesor inútil hayan tenido una rápida repercusión trasatlántica. Incluso aprovecha la ocasión para plantearse si se puede perfilar en la niebla una arquitectura, hacer una novela en la niebla, «flotante sobre las cosas», sin apoyarse en ellas sino por leves alusiones. No es otro - afirma - el problema del arte nuevo y el de la novela más en concreto, formulado pero aún no resuelto. Con todo, aquí cuestiona la posibilidad de una novela poemática: «Cuando se ha querido producir la novela en la misma atmósfera enrarecida del poema puro, creado, se ha obtenido la novela poemática, híbrida e insatisfactoria» (1927g: 1463). Este resultado lo lleva a preguntarse qué otros caminos puede haber, apuntando que el Ortega de La deshumanización del arte, un ensayo «que produjo la reacción típica de los libros fundamentales», ha señalado como porvenir de la novela la creación de psicologías originales (libro de «base psicológica», hemos visto que dice de El profesor inútil). En cualquier caso, descubre en Margarita de niebla los rasgos propios de la narrativa de vanguardia: la escasa anécdota, que relega el tema a un segundo plano; una prosa limpia, ágil, precisa y preciosa; un alegre y difícil tono de levedad intrascendente: «el arte empieza y acaba en sí mismo» (p. 1463). No se puede estar más cerca, con esta defensa de la autonomía del arte propia de la vanguardia, del ideario orteguiano: la deshumanización implica que el arte empieza donde acaba la vida o el hombre que lo hace. Pero insisto en que suscribir el diagnóstico del arte nuevo realizado por el maestro era asumir todo un proyecto político (al fin y al cabo el Ortega de las Meditaciones había reconocido que su filosofía implicaba una política).

Trataré de ahondar en esta cuestión. Pues Ayala recuerda cómo estuvo asistiendo casi a diario, durante años, a la tertulia de la Revista de Occidente. A la vez reconoce el «carácter cerrado» de esa tertulia y de la revista misma, lo cual dio

centenario de Góngora (1928d: 1325-1326). No puede negarse que 1927, si atendemos al gongorismo de los poetas y a los prosistas que menciona «Gecé», ha sido un año dominado por el afán de pureza.

${ }^{12}$ Mucho después, cuando las categorías estéticas de deshumanización y pureza ya han adquirido un valor controvertido, arguye, frente a quienes han esgrimido contra Jarnés «el mal entendido y mal aplicado» concepto orteguiano de deshumanización del arte, que a poca atención que se ponga en la lectura de sus ficciones se descubre «el fuerte ingrediente autobiográfico que contienen» (Ayala 1980: 1474). 
origen a una cantidad enorme de resentimientos en la vida literaria madrileña y a «la acusación de elitista dirigida contra Ortega» (1985: 356). Pese al valor negativo que haya podido adquirir después la noción de elitismo, el del maestro no suponía otra cosa que ajustar su «pensamiento político-social» a la teoría de las élites desarrollada por el sociólogo italiano Vilfredo Pareto, «en la cual encontraba la fórmula perfecta de una democracia fluida bajo grupos directores - las minorías selectas - en continuo proceso de renovación» (p. 356). De suerte que un ensayo como La rebelión de las masas, lejos de militar contra «las justas reivindicaciones del pueblo trabajador», o del desprecio hacia la gente modesta, no suponía otra cosa que el análisis de un tipo humano, el «hombre-masa», concepto que nada tenía que ver con clases sociales o posiciones económicas, pero que hubo de despertar «el amargo rencor de cuantos se sintieron implicados de algún modo en su definición» (p. 357). Indudablemente, la misma ideología liberal de Ayala le hace negar la relación evidente de Ortega con una determinada clase, la burguesa, y con la posición económica, social y política que lleva aparejada. Así llegaron a entenderlo quienes se sintieron implicados en la definición del «hombre-masa», por cuanto participaban de la adscripción a otras ideologías, a otras posiciones sociales, económicas y políticas. Sabemos, con Althusser, que una ideología - que siempre es de clase y desborda con mucho el ámbito de la política - no se presenta como tal ideología. Ayala «solo» presenta a Ortega como un filósofo modernizador y europeísta, situándolo ante todo en el terreno supuestamente neutro de la «cultura», el ámbito al que circunscribe su lectura sociológica de la vanguardia el granadino. Cuando defiende el pensamiento político-social del maestro, el programa «democrático» que estaban realizando en la España del primer tercio del siglo XX las minorías selectas, y por descontando el programa «cultural» y estético que lo acompañaba, se inscribe en una determinada ideología de clase que no se enuncia como tal. En entrevista de 1968 con Andrés Amorós declara que se sumó con entusiasmo al «programa de la vanguardia», dado que «me solicitaba como la forma idónea para expresar la realidad del mundo contemporáneo, de un mundo nuevo» (1972: 98) ${ }^{13}$. Pero al preguntarle el entrevistador por su narrativa juvenil y por la condena que suele recibir esa novela deshumanizada y de la vanguardia, replica que es tan solo una muestra del «palurdismo intelectual» en que cayó España después de la guerra y como consecuencia de ella. El compromiso de Ayala con todo ese programa minoritario, político, cultural e ideológico, de clase en suma, se confunde sin más con la defensa de la literatura y de la cultura como realidades sustanciales y universales, neutras y en sí mismas, con la afirmación de una estética fundada en el presupuesto básico de la autonomía artística (Hernández Guerrero 1992: 134) y en el alejamiento (paradó-

13 Son palabras que deben ponerse en relación con estas otras: «Sentía que la vanguardia, a cuyos movimientos extranjeros y no solo españoles me asomé con ávida curiosidad, era la actitud idónea para dar expresión a la época que estábamos viviendo» (Ayala 2006: 135). 
jico, porque esta defensa de lo literario en sí mismo también oculta un programa ideológico) de todo lo que es tachado de posición política y social manifiesta. $\mathrm{Su}$ compromiso invisible con una determinada ideología —o más bien invisibilizado por esa ideología, ya que la estrategia propia de cualquier discurso ideológico lo hace disfrazarse de no ideológico, borrarse como ideología y presentarse como evidencia - lo induce a distanciarse de cualquier compromiso explícito, a negar que la literatura deba comprometerse.

No se trata de ninguna ocultación astuta y trapacera, sino del funcionamiento de su inconsciente ideológico, pues la ideología se vive de forma inconsciente. Es el inconsciente ideológico de Ayala, su participación en el programa modernizador orteguiano y su inmersión en el horizonte liberal burgués, lo que determina su lectura de la vanguardia y su rechazo de todo compromiso social y político en el escritor, durante aquel entonces y después, porque ese inconsciente ideológico - la ideología estética de la que está impregnado de forma inconsciente este autor y que vive como la verdad misma de las cosas - le dicta que solo debe comprometerse con su literatura y su arte o en todo caso con la «condición humana» (Cerezo Galán 2006: 14). Tan solo desde ese inconsciente puede entenderse la reducción a «palurdismo intelectual» del proceso histórico que lleva a rechazar en la España de posguerra los postulados estéticos deshumanizados de la vanguardia. Sin rehuir el análisis sociológico, Ayala explica a Amorós, y nos explica a todos, cómo «esa posición estrictamente funcionalista» que rechaza cualquier literatura ajena a cuanto es exigencia social inmediata y perentoria se debe a que, interrumpidos en el régimen franquista los «canales ordinarios de discusión política y social», sin medios para ejercer la crítica, se encomienda a la literatura el «ejercicio vicario» de esas actividades indispensables para la salud de una nación, lo cual le parece perfectamente aceptable: «Pero proscribir en nombre de ello cualquier literatura que no sea utilitaria o de combate me parece absurdo. Y en cuanto a la condenación de la vanguardia, además, anacrónico (y en tal sentido he pronunciado la palabra "palurdismo")» (1972: 98). No le falta razón, pero su pensamiento sociológico atenúa y desdibuja todo el proceso histórico, en verdad traumático, que ha conducido en la posguerra a contraponer deshumanización y compromiso, las formas de la vanguardia a las formas de una literatura realista y social. Pese a que, en efecto, la literatura utilitaria no tenía ni tiene por qué proscribir la literatura que no realiza un «ejercicio vicario», en este viraje histórico y literario que sustituía la estética de la vanguardia por una estética rehumanizada y social no solo había anacronismo y palurdismo. Había también realidades insoslayables.

\section{UN VIRAJE EN SECO}

Las greguerías de Ramón Gómez de la Serna y la labor depuradora del ultraísmo, capitaneado por la figura extraña de Cansinos, son los elementos con 
los que Ayala, como hemos visto, traza su propia genealogía vanguardista para hacer desembocar «la joven literatura» en el programa ideológico y político - aunque se cuida mucho de calificarlo así- del nacionalismo liberal orteguiano, correlativo con el programa estético de la deshumanización. Desde aquí, desde este punto nodal, realiza su lectura sociológica de la vanguardia y de la nueva literatura en España. En Recuerdos y olvidos indica que, con la Dictadura de Primo de Rivera, la Monarquía se metió en un callejón sin salida, pues ese lapso de siete años supuso para España la maduración última del proceso que había de, «para usar la expresión grata a Ortega», europeizarla (2006: 159). Según propia confesión, no está haciendo otra cosa que «el perfil histórico-cultural» de aquel periodo. Mientras Primo de Rivera se mantuvo en el poder, afirma líneas después, la sociedad española seguía creciendo por propio impulso interno en los más varios aspectos «y muy particularmente en el de la cultura» (p. 160). Ese poder era considerado un «estorbo interino, y nada más». La literatura «era para nosotros lo primero y principal», hasta el punto de considerar injustificadas, aunque con «base real», las «diatribas feroces» que Unamuno dirigía, en su pelea desde el exilio contra el dictador, a los «intelectuales indiferentes, o anuentes, o renuentes». El argumento no deja de ser curioso: esa, no anuencia, pero sí indiferencia, apunta Ayala (p. 160), «era en el fondo la mejor política», pues la fruta al fin y al cabo iba a caer por su propio peso, por su madurez y estado de putrefacción (y no deja de ser sintomático que recuerde, a la hora de justificar este apoliticismo de los jóvenes en aquel momento, cómo se aplicaba el adjetivo «putrefacto» a todo lo que no respondía a «los valores de novedad y pureza que tanto estimábamos nosotros»: «la Monarquía, putrefacta»). Mostrando en otra ocasión el desapego hacia los postulados nacionalistas de las dos generaciones previas a la suya, se refiere de nuevo a «cierto memorable episodio de la vida civil de la época», la indignación del Unamuno enzarzado contra el dictador y el Rey por la «frívola» indiferencia que mostraban los jóvenes, para dejar claro que si los escritores de vanguardia, «suma de movimientos de implantación e inspiración internacional», echaban mano en España de la temática nacional era para tratarla con un «irónico regodeo estetizante» que la colocaba a «distancia aséptica», como prueba el «monóculo deshumanizador» con el que Gómez de la Serna se acerca al casticismo o el «tono lúdico» con el que abordan este mismo aspecto Giménez Caballero, Lorca y Alberti (1997a: 1217). La Dictadura de Primo de Rivera - dirá más claramente aún — fue vivida por la gente joven, «por la gente de mi grupo», como un interregno que venía a liquidar un régimen, por lo que se la recibió muy bien al comienzo: «La tónica dominante era, si no de entusiasmo, sí al menos de aprobación» (1992c: 1591). Entre los del 98, Valle-Inclán la combatió por motivos en el fondo estéticos, y Unamuno, «con su estilo personalista», dio a su disputa un tono de tragedia, pero entre los jóvenes, más cercanos a los «actos teatrales» montados por el primero - «ilustre escritor y extravagante ciudadano», en palabras del dictador-, predominaba un 
rechazo desdeñoso y «la confianza en que el régimen caería por su propio agotamiento, como así fue» (p. 1591).

Me detendré en un texto que ilustra muy bien esta curiosa política del apoliticismo, este compromiso del autor con la literatura ante todo («lo primero y principal») y con la vanguardia absorbida por el programa liberal orteguiano $^{14}$. El propio Ayala recuerda su contestación en febrero de 1928 a la encuesta sobre política y literatura que La Gaceta Literaria dirigió a la juventud poética española (1992d: 759). A la pregunta de si debe intervenir la política en literatura responde que, si por ello se entiende que el escritor haga política en su obra literaria, le parece muy mal, «una mixtificación insoportable, que es la últimamente realizada por la generación del 98» (1928e: 537). La nueva generación, «más fina de espíritu», ha evitado tales «confusiones» y a nadie se le ocurre hoy hablar de política en un soneto. A la segunda pregunta, «¿Siente usted la política?», contesta que la siente con intensidad, como espectáculo y sobre todo como actuación: un intelectual no puede eludir cierta atención a la política, porque de otro modo «no será un intelectual, sino un señorito profesional». Pero aquí viene el matiz para comprender la separación nítida y constante que establece entre política y literatura: «Lo que no se le puede pedir es que esa atención sea preferente, ni menos, que escriba sobre el asunto» (p. 537). A la última pregunta, «¿Qué ideas considera fundamentales para el porvenir del Estado español?», responde, en fin, que la misión del escritor no es lanzar programas y que «no soy hombre de principios (políticos)», si bien, en su opinión, no cabe ignorar que «el progreso material de la civilización -aviación, telegrafía sin hilos, etc. - requiere urgente internacionalismo» (p. 537). Mucho después explica esta posición aclarando que España vivía el «lapso de suspensa esperanza» abierto por la Dictadura de Primo de Rivera y que su generación, superado el nacionalismo de las anteriores y ya europeizada, sentía, a la vista del progreso civilizatorio (reducido sin embargo «todavía» a la aviación y la telegrafía sin hilos, como le hemos visto decir en la encuesta), la necesidad de una «ordenación internacional del mundo» (1992d: 760). No justifica de otro modo su aparente apoliticismo, su no ser un hombre de principios (políticos) a finales de los 20 , cuando en realidad estaba colaborando con la política reformista y europeísta liberal; de aquí sus observaciones sobre cómo dominaba entre los jóvenes una «tónica de aplomo», porque «España, y nosotros con ella, estaba colocada ya en el plano de la actualidad mundial», al menos en la esfera de la cultura, pues en otros aspectos «la nación como tal» seguía situada al margen de la corriente histórica y pronto habrían de padecerse los efectos de esta antigua marginación suya, con el crack del 29, el ascenso del fascismo ante los «paralizados regímenes liberales» y la guerra españo-

14 José Luis Cano (2006: 24) ya reparaba en que la imagen de los años 20 que nos da Ayala en sus memorias es «la de una vida literaria intensa, en la que la literatura era lo importante y la política importaba menos». 
la, prólogo de la conflagración mundial (p. 760). Tal lectura de los hechos revela con claridad los principios políticos del autor, antes y después de que ese programa de sincronización cultural se desvaneciera. Como reconoce en otro lugar, la renovación literaria que representaba la vanguardia, a la cual se incorporó con entusiasmo, correspondía a los últimos tiempos de la fe progresista, a la atmósfera de optimismo que se respiraba tras la Primera Guerra Mundial y la Revolución Rusa. Esa atmósfera se tradujo en «un arte ágil, libre, juguetón, arriesgado, brillante, cuya versión literaria se complacía en la metáfora sorprendente, en la pirueta divertida, en la ingeniosidad» (1990: 44). Pero pronto se posaron sobre las cabezas de aquellos alegres vanguardistas los negros nubarrones que descargaron en las dos guerras, la española y la europea, «desmintiendo así las felices expectativas previas y poniendo término a la utopía progresista» (p. 44). Ayala se refiere incluso a cómo el último de sus relatos vanguardistas, «Erika ante el invierno», responde bajo su luminoso metaforizar al presentimiento sombrío de la gran tragedia en ciernes. No es una idea nueva en él, como veremos.

Tan pronto como en 1931, intentando una interpretación histórica del «bloque, no de hechos, sino de estilos de la sensibilidad» comprendido entre 1918 y 1930, ya había dado por irremediablemente tramontado lo que «ayer todavía era actualísima ilusión, goce puro de un arte puro y ahora infantil del mundo». El periodo de posguerra - afirma - ha pasado, con su ilusión, con sus cualidades pueriles y la «especial autoridad de lo nuevo y de lo joven», con su «rara acuidad para lo que presentase un perfil original, para las facetas del humor y para los saltos del ingenio» (1931a: 573). Toda esa época se ha distinguido por la «pureza» en el método de las ciencias y en la intención de las artes. Tras este panorama arcádico, de risas y deporte, el mundo ha hecho un «viraje en seco» y «se ha puesto serio de repente». No cabe duda de que Ayala se refiere a las nuevas circunstancias sociales e históricas que están dejando atrás el tiempo de la deshumanización y la pureza, de la vanguardia estética en general: «Toda una promoción literaria ha encontrado, de pronto, su adultez. Ha tirado los juguetes, y ahora se siente desconcertada porque, en cierto modo, había hecho profesión de la edad infantil» (p. 575) ${ }^{15}$. Tan certero análisis, realizado

15 Sintomáticamente, a 1931 lo considera «un año de renacer político y mudez poética» al reseñar un libro de Salazar Chapela (1931b: 661). Por las mismas fechas aprecia dos líneas directrices en la «nueva literatura» española: la de los superrealistas, que viven artísticamente de negar el arte, y la literatura social, que trae el «menosprecio de los valores estéticos» y la «subordinación del arte a los valores de orden ético, humanos» (1931c: 1467). No deja de señalar, con todo, que, a diferencia de España, «donde los escritores que son algo han buscado y perseguido imágenes puras, de puro sueño poético, y las han encerrado en ámbitos verbales reservados a la minoría», Alemania cultiva por entonces, bajo la irradiación de la estrella soviética, buena literatura y «mala doctrina literaria - la doctrina que sostiene la inanidad de un arte puro, sin preocupación social; lo deleznable de cuanto no sea humano, entiéndase: demasiado humano, infrahumano» (p. 1468). Es fácil notar la incomodidad, ante 
como una anotación en el margen del calendario, adelanta el autoexamen que lleva a cabo en el mencionado prólogo a La cabeza del cordero ${ }^{16}$. Quien habla en este proemio, como en tantos otros lugares, es el Ayala autocrítico, una «especie de persona creada» por el propio autor (Richmond 1995: 29), el Ayala que se contempla a sí mismo en el espejo de su obra y su tiempo para actuar como guía de lectores desamparados (Richmond 1998a: 20). De suerte que en este polémico texto, incluido en Confrontaciones, estima necesario referirse a su contacto con los grupos de vanguardia y a sus relatos deshumanizados, cuya base de experiencia se reducía a «cualquier insignificancia», desde la cual se alzaba «la pura ficción en formas de una retórica nueva y rebuscada, cargada de imágenes sensoriales» (Ayala 1972: 187). La tónica de aquellos años consistió - admite ahora - en hacer tabla rasa de lo anterior con el propósito de constituir un mundo nuevo, dinámico y brillante, de ruptura con el pasado, en literatura como en todo lo demás. Los jóvenes tenían la palabra - pensemos en la autoridad de «lo joven» a la que toma el pulso en 1931- y se les invitaba a la insolencia, al disparate gratuito: «El balbuceo, la imagen fresca, o bien el jugueteo irresponsable, los ejercicios de agilidad, la eutrapelia, la ocurrencia libre, eran así los valores literarios de más alta cotización» (p. 187). Pero pronto pasaron la oportunidad y el ambiente de «aquel poetizar florido, en que yo hube de participar también a mi manera».

Resulta innegable que estamos ante una palinodia, aunque el propio autor tratará posteriormente de diluirla ${ }^{17}$. El prosista deshumanizado y puro se ha rehumanizado. La gravedad hosca de los acontecimientos que comenzaban a barruntarse - explica — ensombreció aquella «aurora» y «yo por mí, me reduje a silencio» (1972: 188). Por supuesto, este silencio se debe al choque de su ideología estética, la que viene de practicar, con las nuevas circunstancias y la nueva literatura social que se está imponiendo, al conflicto entre un compro-

la doctrina de la literatura social, de un Ayala que ha practicado esa literatura pura, deshumanizada y minoritaria.

${ }^{16}$ García Montero comenta la perspicacia de Ayala en este artículo de 1931 y lo pone en relación con ese prólogo publicado dieciocho años después (1992: 352-353, 2009: 62 y 2011: 93-94, 106). Mainer (2014: XXV) anota con oportunidad — si tenemos en cuenta que este artículo supone una «recapitulación lúcida sobre el pasado inmediato, el general y el suyo» (Soria Olmedo 2006: 213) — que se publicó en el número del 1 de mayo de $L a G a$ ceta Literaria, recién proclamada la República.

17 Véanse las conversaciones con Hiriart $(2014: 84,91)$. Ayala considera exageradas las interpretaciones que se han hecho de este prólogo pues, lejos de renegar de su fase vanguardista, la incorpora después a cuanto escribe. No extraña así que la crítica, salvo alguna excepción (Fortes 1992), haya relativizado las posiciones tomadas en este texto (Mainer 2001: 248; Cózar 1995: 41; Viñas Piquer 2000: 120-121) o haya señalado las «constantes vanguardistas» de la escritura ayaliana (Richmond 1998b), cuestionando incluso la deshumanización y pureza de los primeros relatos (Cózar 1998: 35), en los que, más cerca de la realidad de las cosas, Mainer (1989: 74-75) detecta una «acumulación de presencias puras». 
miso que nunca se define como tal, invisible o invisibilizado, y el compromiso manifiesto de la «literatura de avanzada» o en general de la vanguardia política. Ayala prefiere narrarlo así: requerido por otras urgencias e intereses (esto es: separando política y literatura, divorciando al ciudadano o al intelectual del creador), puso tregua a su gusto de escribir ficciones, «y acudí con mi pluma al empeño de dilucidar los temas penosísimos, oscuros y desgraciados que tocaban a nuestro destino, al destino de un mundo repentinamente destituido de sus ilusiones» (p. 188). La que sería su última narración vanguardista, «Erika ante el invierno», fue interpretada entonces por su amigo el hispanista alemán Walter Pabst como un reflejo del dolor desesperado que afligía a Europa, aunque Ayala confiesa que en realidad no había pretendido hacer eso, sino «seguir tanteando en la dirección estética elegida». No obstante, desde el hoy en que lee su producción vanguardista, le da la razón. Su estancia en Berlín por los años 29 y 30, los de despliegue del nazismo, infundió en su ánimo la intuición de las «tremendas realidades» que se incubaban, ante cuya perspectiva perdía todo sentido «aquel jugueteo literario, estetizante y gratuito a que estábamos entregados» (p. 188). Continuando con el examen de conciencia, en fin, vuelve a referirse a la «pausa nacional» impuesta por la Dictadura de Primo de Rivera, a la atmósfera de paréntesis y espera en que la «nueva generación» literaria se manifestó muy desligada de las realidades inmediatas, «a través de actitudes estéticas que pretendían el máximo distanciamiento respecto del ambiente social» (p. 190). ¿Dónde queda en este prólogo el compromiso al que se adhieren en los años 30 algunos miembros de esa «generación»? En ningún momento se menciona.

\section{EL COMPROMISO CON LA CONDICIÓN HUMANA}

Quince años después, en el artículo «Función social de la literatura», publicado en Revista de Occidente y también incluido en Confrontaciones, la herida se ha cerrado y Ayala ha comenzado a dar un lugar no traumático a su producción vanguardista y a la vanguardia en general en su historia literaria. Nos dice aquí que, en la atmósfera de confianza y seguridad que siguió a la Gran Guerra, la literatura pudo avanzar, como la pintura y la música, en la dirección de «la pura gratuidad estética» y la deshumanización del arte descrita por Ortega. La literatura no tenía por qué cargarse de intenciones ajenas a ella, políticas, económicas, sociales, porque cada una de estas disponía de su «vehículo idóneo» en aquel momento. Nada impedía tomar este otro rumbo, con todo, y pone como ejemplo las diatribas poéticas de Unamuno contra Primo de Rivera y el Rey, o «un par de novelas» de Sender y Díaz Fernández (Imán y El blocao, como más abajo especifica), aunque la nueva generación vio esa poesía y esa novela político-social como «fruto de una actitud anticuada, como supervivencia romántica y naturalista» (1972: 245). Lo decisivo, en 
cualquier caso, es que, aunque confiesa que el término de deshumanización no le satisfizo nunca y tiene «virtudes irritantes» tal y como lo usó Ortega, ve en el cultivo de un arte primordialmente orientado por el valor estético «un motivo perfectamente humano» y le adjudica un «fin social muy claro» dentro de las condiciones culturales que entonces prevalecían, las de una España instalada de lleno, después de varios siglos, en Europa. Lejos de lo planteado en el prólogo de 1949, adjudica ahora una "conciencia político-social bien despierta» a los cultivadores de la literatura que se moteja de deshumanizada y a los escritores de la vanguardia en general (pp. 246-247). Si los primeros eran «españoles europeos» o «europeos españoles», los segundos cantaban un mundo libre, ágil, aséptico y eficiente, el alumbrado por la tecnología, y al hombre nuevo que la sociedad había gestado, al «obrero liberado», y de aquí el crédito que, con «universal simpatía», abrieron los intelectuales de entonces a la Revolución Rusa. Incluso, por este camino de legitimación de su producción vanguardista, acaba viendo en la frivolidad y la despreocupación juvenil de entonces, en su jugueteo literario «al parecer» intrascendente, un camino conmovedor para alcanzar «la esencial condición humana» (p. 249). Hay que poner el texto que comentamos y el prólogo de 1949 frente a frente, como en un espejo. Al mismo tiempo que deslíe el compromiso de su primera etapa narrativa con una determinada ideología mediante esta imagen de la esencial condición humana, y al mismo tiempo que justifica la «responsabilidad» de su producción vanguardista y cierra la herida abierta por él mismo quince años antes, Ayala deslegitima todo engagement, toda literatura social al considerarla «anacrónica» no ya solo en una Europa próspera y socialmente avanzada sino también en una España que se está incorporando, pese al franquismo, a la vida económica occidental (pp. 250-251). No son sino su deuda con la autonomía del arte, con la ideología estética hegemónica en su juventud, su ethos humanista y liberal burgués y su concepción fenomenológica del hecho literario (Villanueva 1992; Linares 2004: 93-94), lo que le hace practicar una suerte de «epoché ideológica» (Cerezo Galán 2006: 13) y concluir que «los escritores han de buscar la radical autenticidad del ser humano a través de una interpretación directa y sin compromiso - la sinceridad constituye el único compromiso del verdadero artista - de la concreta coyuntura histórica en que se encuentran» (Ayala 1972: 252). No se trata de hacer una lectura «politizadora» e «ideologizante», tendenciosa, de Ayala. Mi intención es subrayar una serie de contradicciones sobre las que no se ha reparado aún: la concepción esencialista del «ser humano», a la que liga su literatura, le hace caer en el «repudio de la historia» que él mismo lamenta con la llegada de la posmodernidad (1992b: 752-755) y trascender toda coyuntura histórica concreta en la inmutable naturaleza humana, la categoría con la que en última instancia se compromete o lo compromete su inconsciente ideológico. Como si, a fin de cuentas, lo de menos fuese el mundo que todo intelectual o escritor lleva a la espalda, por hacer un guiño a un título suyo. 
La forma de responder a la encuesta que, sobre esta cuestión del compromiso, formula el Almanaque literario de 1935 es muy ilustrativa de su doble lectura —estética y sociológica (Chicharro 2006a: 251-252 y 2006b: 203) — del arte o la literatura, nunca contradictoria para él. Toma la palabra, en primer lugar, el defensor de la estética: el propósito del arte, que es un «producto de la cultura», es crear un valor: la Belleza (así, en mayúscula). Pero el contenido de la obra de arte viene determinado por «factores sociales», de modo que el «reciente y ya pasado programa de realizar un arte puro» comporta en sí mismo una posición política y social, «por cuanto que toda neutralización favorece el statu quo» (1935: 1650). Por lo tanto, no falta razón a los escritores y artistas proletarios - concluye - «cuando tachan de burgués al arte puro». Indirectamente, el Ayala sociólogo pone al descubierto su compromiso, como escritor de vanguardia, con una determinada ideología ${ }^{18}$. Ahora bien, el inconsciente artístico de la pureza, su inconsciente ideológico en general, lo obliga enseguida a matizar que «subordinar la intención estética y ponerla al servicio de ideales ajenos a ella, políticos o sociales, avanzados o reaccionarios, es colocarse en la actitud del político, y no en la del artista», pues dicho queda que el sentido de la obra de arte es realizar la Belleza, y sin ello no puede explicarse (p. 1651). Bien es verdad que, como añade todavía, un poema puro puede ser un producto deleznable, y un panfleto político o una película de propaganda llevar una carga de enorme acierto estético. Varios textos posteriores, con todo, muestran un claro desapego no ya hacia la literatura de propaganda, sino hacia cualquier tipo de compromiso, como no sea con la literatura en sí misma y el universal humanista burgués del «espíritu» o la condición humana ${ }^{19}$. Así, en «El escritor enrolado», una breve nota de 1948 incluida en Confrontaciones, se lee que la fórmula de Sartre resulta «desdichada en extremo», porque predicar el engagement exhorta a tomar partido y «cumplir la tarea literaria dentro de consignas impuestas por autoridades políticas» (1972: 333). La dignidad del hombre de letras no es otra que «la del hombre en su esencia y plenitud», el auténtico engagement no es sino «el uso de la libertad», como en verdad plantea Sartre al remitir esta cuestión a su «concepción filosófica». El sociólogo que hay en Ayala reconoce que la teoría del arte por el arte responde a una determinada situación social y opera sobre ella, pero el

18 Naturalmente, el compromiso ideológico del que hablo es una noción distinta, como fácilmente podrá deducirse, de esa «ética de la escritura», de esa compatibilidad (aunque no «perfecto equilibrio») entre «compromiso estético» y «compromiso ético» que Viñas Piquer (2000) encuentra en la literatura vanguardista de Ayala al leerla desde los postulados teóricos de Barthes (la «moral de la forma»), Bourdieu (el arte puro como una posición social), Adorno (la «estética de la negatividad») o Bürguer (la nueva manera de conectar compromiso y obra artística en las creaciones «inorgánicas» de la vanguardia).

19 Por eso, como señala Mainer (2006: 12), el concepto de intelectual manejado por Ayala es «inevitablemente reminiscente» del Julien Benda de La trahison des clercs (1927). 
esteta que a la vez hay en él considera «sospechosa» la teoría opuesta del engagement o del arte al servicio de la sociedad, pues impulsa al artista a crear bajo consignas y coarta su «libertad creadora» (1964: 1652) ${ }^{20}$. Pero, ¿dónde queda entonces el reconocimiento filosófico de la libertad al Sartre engagé?

Sin mayores distingos, que tanto se cuida de hacer el autor de ¿Qué es la literatura?, el Ayala esteta confunde engagement y realismo socialista: «El escritor se debe a sí mismo, su compromiso es fidelidad consigo mismo, no con un partido político o con un jefe» (1996a: 1645) ${ }^{21}$. La «obra de creación literaria», y no cree que deba tacharse de esteticista esta tesis, no ha de ser intencionalmente concebida como un instrumento para la praxis, «pues si con tal intención se escribe será a expensas de perjudicar su calidad artística y, lo que resulta irónico, en detrimento de su eficacia para la praxis a la que pretende servir» (1988b: 509-510). ¿Acaso Sartre y los escritores comprometidos más lúcidos han mantenido otra cosa? Ayala parece olvidar lo que, como hemos visto, había dicho en 1935: que puede haber mala literatura pura o de «creación» y buena literatura social o comprometida. Olvida también que hay formas de compromiso ideológico más invisibles o invisibilizadas que el compromiso político manifiesto de servir a un partido o a un jefe. Ese compromiso ideológico palpita, como se ha intentado mostrar aquí, en su incorporación a la vanguardia y en la lectura posterior de su producción juvenil. Lo curioso es que asienta este compromiso en el divorcio radical entre literatura y política, invisibilizándolo como compromiso. Lo hace el creador literario o el esteta en contra del sociólogo. El arte nunca fue para él — asegura - un arma. Esgrimirlo como tal es degradarlo y degradarse al hacerlo. Es una opinión que tiene por «demasiado cuestionable» y que no quiere elevar a «principio universal», pero confiesa que siempre la ha convertido en norma de su propia conducta. Por ello, no solo durante la guerra, sino también durante el turbulento periodo precedente, se abstuvo de «hacer acto de presencia en la vida pública como creador literario», aunque sin regatear «los esfuerzos que otras capacidades mías pudieron permitirme llevar a cabo en defensa de la causa que me creía en el deber de sostener» (1996b: 796-797). Hay silencios literarios que comprometen. Instalado en el inconsciente estético de la «creación» y de la autonomía del arte, que se correspondieron en su caso con un programa cultural, político e ideológico, el del nacionalismo liberal y las minorías que encauzan la vanguardia hacia la sincronización con Europa y la vertebración de España, Ayala

${ }^{20}$ La autonomía y la historicidad del arte coexisten sin ninguna dificultad en el pensamiento sociológico-literario de Ayala, para quien a estas alturas ya no vale el formalismo puro kantiano, aunque mucho menos el hegelianismo contenidista (Chicharro 2006b: $211 \mathrm{y}$ 2006c: 35), ya que en él se apoya la llamada literatura social o la noción tópica de compromiso.

${ }^{21}$ Encontramos las mismas palabras en su conversación con González del Valle (1990: 90-91). 
traza una raya nítida en sus funciones de «intelectual de conciencia» (Mainer 1992: 42) y distingue entre el compromiso con una causa política y su compromiso consigo mismo, con la escritura y la invención artística. El Ayala creador contradice y desautoriza en este punto concreto al Ayala sociólogo, del que tantas veces se surte el Ayala crítico e historiador literario.

\section{FUENTES}

Ayala, Francisco (1927a). «Un cuaderno de ejercicios», en Ayala (2014), pp. 510-512.

Ayala, Francisco (1927b). «Ramón y las cosas», en Ayala (2014), pp. 484-488.

Ayala, Francisco (1927c). «Poemas interdictos», en Ayala (2014), pp. 456-458.

Ayala, Francisco (1927d). «Madrid-América. Guillermo de Torre», en Ayala (2014), pp. 503-508.

Ayala, Francisco (1927e). «El profesor inútil», en Ayala (2014), pp. 481-484.

Ayala, Francisco (1927f). «Pájaro pinto», en Ayala (2014), pp. 488-490.

Ayala, Francisco (1927g). «Margarita de niebla», en Ayala (2007), pp. 1461-1464.

Ayala, Francisco (1928a). «Las tertulias literarias», en Ayala (2014), pp. 1317-1324.

Ayala, Francisco (1928b). «C. M. Arconada: Urbe», en Ayala (2014), pp. 547-549.

Ayala, Francisco (1928c). "Apuntes para una visión de la joven literatura española», en Ayala (2014), pp. 576-581.

Ayala, Francisco (1928d). «Lo que ha dado 1927. Y lo que se espera de 1928», en Ayala (2014), pp. 1325-1334.

Ayala, Francisco (1928e). «Política y literatura. Una encuesta a la juventud española», en Ayala (2014), pp. 536-537.

Ayala, Francisco (1929). «Paula y Paulita», en Ayala (2014), pp. 552-554.

Ayala, Francisco (1931a). «Anotación en el margen del calendario», en Ayala (2014), pp. $572-575$.

Ayala, Francisco (1931b). «Crítica literaria. Un libro singular», en Ayala (2014), pp. 661-662. Ayala, Francisco (1931c). «Berlín-Norte», en Ayala (2007), pp. 1467-1470.

Ayala, Francisco (1935). «Respuesta a una encuesta publicada en el Almanaque literario, 1935», en Ayala (2014), pp. 1650-1651.

Ayala, Francisco (1964). «Respuesta a una encuesta sobre arte y libertad», en Ayala (2014), pp. 1651-1653.

Ayala, Francisco (1972). Confrontaciones, en Ayala (2014), pp. 65-350.

Ayala, Francisco (1980). «Lo rojo y lo azul», en Ayala (2014), pp. 1470-1475.

Ayala, Francisco (1985). La retórica del periodismo y otras retóricas, en Ayala (2013), pp. 285-394.

Ayala, Francisco (1988a). «Retratos de España», en Ayala (2014), pp. 1492-1497.

Ayala, Francisco (1988b). Mi cuarto a espadas, en Ayala (2013), pp. 395-574.

Ayala, Francisco (1990). El escritor en su siglo, en Ayala (2007), pp. 37-455.

Ayala, Francisco (1992a). «Ramón Gómez de la Serna», en Ayala (2014), pp. 1367-1377.

Ayala, Francisco (1992b). Contra el poder y otros ensayos, en Ayala (2013), pp. 575-755.

Ayala, Francisco (1992c). «Entrevista. Los intelectuales y la política, por Santos Juliá», en Ayala (2014), pp. 1588-1606.

Ayala, Francisco (1992d). El tiempo y yo, o el mundo a la espalda, en Ayala (2010), pp. 711-939. 
Ayala, Francisco (1996a). «Encuentro con Francisco Ayala, por Ángel García Galiano», en Ayala (2014), pp. 1627-1649.

Ayala, Francisco (1996b). En qué mundo vivimos, en Ayala (2013), pp. 757-837.

Ayala, Francisco (1997a). «El nacionalismo tardío de la generación del 98», en Ayala (2014), pp. $1210-1218$.

Ayala, Francisco (1997b). «Un esplendor final», en Ayala (2013), pp. 1074-1077.

Ayala, Francisco (2006). Recuerdos y olvidos (1906-2006), en Ayala (2010), pp. 47-707.

Ayala, Francisco (2007). Obras completas III. Estudios literarios. Ed. de Carolyn Richmond. Pról. de Ricardo Senabre. Barcelona: Círculo de Lectores/Galaxia Gutenberg.

Ayala, Francisco (2008) [1957]. Tratado de sociología, en Obras completas IV. Sociología y ciencias sociales. Ed. de Carolyn Richmond. Pról. de Salvador Giner. Barcelona: Círculo de Lectores/Galaxia Gutenberg, pp. 39-864.

Ayala, Francisco (2010). Obras completas II. Autobiografia(s). Ed. de Carolyn Richmond. Pról. de Luis García Montero. Barcelona: Círculo de Lectores/Galaxia Gutenberg.

Ayala, Francisco (2013). Obras completas VI. De vuelta en casa (Colaboraciones en prensa 1976-2005). Ed. de Carolyn Richmond. Pról. de Santos Juliá. Barcelona: Círculo de Lectores/Galaxia Gutenberg.

Ayala, Francisco (2014). Obras completas VII. Confrontaciones y otros escritos (1923-2006). Ed. de Carolyn Richmond. Pról. de José-Carlos Mainer. Barcelona: Círculo de Lectores/ Galaxia Gutenberg.

\section{BIBLIOGRAFÍA CITADA}

Aznar Soler, Manuel (2010). República literaria y revolución (1920-1939). Sevilla: Renacimiento, 2 vols.

Caballero Bonald, José Manuel (2006). «Ayala, vanguardista», en Luis García Montero (ed.), Francisco Ayala. De mis pasos en la tierra. Málaga: Junta de Andalucía, pp. 265-267.

Cáceres Sánchez, Manuel (1992). «Francisco Ayala y los estudios sobre el pensamiento estético-literario de José Ortega y Gasset», en Antonio Sánchez Trigueros y Antonio Chicharro (eds.), Francisco Ayala, teórico y crítico literario. Granada: Diputación de Granada, pp. 239-251.

Cano, José Luis (2006) [1982]. «Francisco Ayala y sus memorias», Ínsula. 718, p. 24.

Cano Ballesta, Juan (1996). La poesía española entre pureza y revolución (1920-1936). Madrid: Siglo XXI.

Cerezo Galán, Pedro (2006). «Francisco Ayala o el ethos de la libertad», en Francisco Ayala, Ensayos politicos. Libertad y liberalismo. Madrid: Biblioteca Nueva, pp. 11-49.

Chicharro, Antonio (1992). «Francisco Ayala, crítico y crítico de la crítica», en Antonio Sánchez Trigueros y Antonio Chicharro (eds.), Francisco Ayala, teórico y crítico literario. Granada: Diputación de Granada pp. 253-264.

Chicharro, Antonio (2006a). «De palabras como plumas (una aproximación a la teoría y la crítica literaria de Francisco Ayala)», en Luis García Montero (ed.), Francisco Ayala. De mis pasos en la tierra. Málaga: Junta de Andalucía, pp. 245-263.

Chicharro, Antonio (2006b). «Razón histórica y razón disciplinar en el estudio sociológico del arte de Francisco Ayala (Aspectos introductorios)», en Antonio Sánchez Trigueros y Manuel Ángel Vázquez Medel (eds.), Francisco Ayala y América. Sevilla: Alfar, pp. 193-215. 
Chicharro, Antonio (2006c). El pensamiento vivo de Francisco Ayala (Una introducción a su sociología del arte y crítica literaria). Granada: Dauro.

Cózar, Rafael de (1995). «Francisco Ayala: de la vanguardia a la permanente actualidad», en Manuel Ángel Vázquez Medel (ed.), El universo plural de Francisco Ayala. Sevilla: Alfar, pp. 31-50.

Cózar, Rafael de (1998). «Los inicios vanguardistas de Francisco Ayala: Cazador en el alba y El boxeador y un ángel», en Manuel Ángel Vázquez Medel (ed.), Francisco Ayala y las vanguardias. Sevilla: Alfar, pp. 33-44.

Fortes, José Antonio (1992). «Del prólogo a La cabeza del cordero. Una lectura», en Antonio Sánchez Trigueros y Antonio Chicharro (eds.), Francisco Ayala, teórico y crítico literario. Granada: Diputación de Granada, pp. 287-299.

García, Miguel Ángel (2001). «Los signos del mapa (Vanguardia/compromiso como polos opuestos)», en El Veintisiete en vanguardia. Valencia: Pre-Textos, pp. 29-42.

García, Miguel Ángel (2011). «¿Hacia una reconfiguración radical del canon? El Veintisiete y la dialéctica de la vanguardia en España», Anales de la Literatura Española Contemporánea. 36 (1), pp. 55-80.

García, Miguel Ángel (2013). «Vanguardia, avanzada, revolución (1927-1936). La querella del canon poético y del compromiso», en Araceli Iravedra (ed.), Políticas poéticas. De canon y compromiso en la poesía española del siglo XX. Madrid - Frankurt am Main: Iberoamericana - Vervuert, pp. 67-112.

García, Miguel Ángel (2016a). «Prólogo», en Andrés Soria Olmedo, Vanguardismo y crítica literaria en España (1909-1930). Barcelona: Calambur, pp. 13-31.

García, Miguel Ángel (2016b). «Novelar filosofía. La autobiografía intelectual de Rosa Chacel y la vanguardia española», Anuario de Estudios Filológicos. XXXIX, pp. 109126.

García Montero, Luis (1992). «Francisco Ayala, poesía y cine», en Antonio Sánchez Trigueros y Antonio Chicharro (eds.), Francisco Ayala, teórico y crítico literario. Granada: Diputación de Granada, pp. 347-358.

García Montero, Luis (1995). «El cine y la mirada moderna», en Manuel Ángel Vázquez Medel (ed.) El universo plural de Francisco Ayala. Sevilla: Alfar, pp. 51-67.

García Montero, Luis (2006). Francisco Ayala y el cine. Madrid: Visor.

García Montero, Luis (2009). Francisco Ayala. El escritor en su siglo. Granada: Diputación de Granada.

García Montero, Luis (2011). «Antes, durante, después (Francisco Ayala y la Guerra Civil)», en Luis García Montero y Milena Rodríguez Gutiérrez (eds.), De este mundo y los otros. Estudios sobre Francisco Ayala. Madrid: Visor, pp. 93-111.

Geist, Anthony Leo (1980). La poética de la generación del 27 y las revistas literarias: de la vanguardia al compromiso (1918-1936). Barcelona: Labor.

Glenn, Kathleen (1990). «Conversación con Rosa Chacel», Letras Peninsulares. 3 (1), pp. 11-26.

González del Valle, Luis T. (1990). «Conversación con Francisco Ayala», Letras Peninsulares. 3 (1), pp. 85-93.

Hernández Guerrero, José Antonio (1992). «La teoría literaria de Francisco Ayala», en Antonio Sánchez Trigueros y Antonio Chicharro (eds.), Francisco Ayala, teórico y crítico literario. Granada: Diputación de Granada, pp. 133-141.

Hiriart, Rosario (2014). Conversaciones con Francisco Ayala. Granada: Fundación Francisco Ayala - Universidad de Granada.

Jiménez Millán, Antonio (1980). «Pureza y compromiso en la generación del 27», en Lecturas del 27. Granada: Universidad de Granada, pp. 201-246. 
Lapesa, Rafael (1988). De Ayala a Ayala. Estudios literarios y estilísticos. Madrid: Istmo.

Linares, Francisco (2004). «La crítica literaria de Francisco Ayala (Diálogo con el tiempo)», en Antonio Sánchez Trigueros y Manuel Ángel Vázquez Medel (eds.), El tiempo y yo. Encuentro con Francisco Ayala y su obra. Sevilla: Alfar, pp. 93-106.

Mainer, José-Carlos (1989). «La prosa de vanguardia», en Francisco Ayala. Premio Nacional de las Letras Españolas 1988. Barcelona: Anthropos, pp. 67-80.

Mainer, José-Carlos (1992). «Una reflexión sobre los poderes del intelectual», en Antonio Sánchez Trigueros y Antonio Chicharro (eds.), Francisco Ayala, teórico y crítico literario. Granada: Diputación de Granada, pp. 41-48.

Mainer, José-Carlos (2001). «Francisco Ayala en sus prólogos: retratos y avisos», en JeanFrançois Botrel, Yvan Lissorgues, Christopher Maurer y Leonardo Romero Tobar (coords.), Prosa y poesía. Homenaje a Gonzalo Sobejano. Madrid: Gredos, pp. 241-254.

Mainer, José-Carlos (2006). «Desde el centro de la realidad: Francisco Ayala entre nosotros», Turia. 77-78, pp. 9-21.

Mainer, José-Carlos (2014). «Notas para el mapa de una vida», en Francisco Ayala, Obras completas VII. Confrontaciones y otros escritos (1923-2006), ed. Carolyn Richmond; prol. José-Carlos Mainer. Barcelona: Círculo de Lectores - Galaxia Gutenberg, pp. XXI-L.

Matamoro, Blas (2009). "Chacel y Ayala: formas de eludir el exilio», Cuadernos Hispanoamericanos. 714, pp. 71-90.

Mora Sánchez, Miguel Ángel (1992). «La crítica de Ayala a la novela española de vanguardia: algunas reseñas publicadas en la Revista de Occidente y La Gaceta Literaria», en Antonio Sánchez Trigueros y Antonio Chicharro (eds.), Francisco Ayala, teórico y crítico literario. Granada: Diputación de Granada, pp. 229-237.

Navarro Durán, Rosa (2006). «Las prosas vanguardistas de Francisco Ayala: una ventana abierta a la belleza y el ingenio», en Susana Martínez-Garrido (coord.), Francisco Ayala. El escritor en su siglo. Madrid: Sociedad Estatal de Conmemoraciones Culturales, pp. 393-404.

Pérez Bazo, Javier (1992). Juan Chabás y su tiempo. De la poética de vanguardia a la estética del compromiso. Barcelona: Anthropos.

Pulido Tirado, Genara (1992). «La etapa crítico-literaria de Francisco Ayala en la Revista de Occidente (1927-1930)», en Antonio Sánchez Trigueros y Antonio Chicharro (eds.), Francisco Ayala, teórico y crítico literario. Granada: Diputación de Granada, pp. 215-227.

Ribes Leiva, Alberto J. (2007). Paisajes del siglo XX: sociología y literatura en Francisco Ayala. Madrid: Biblioteca Nueva.

Richmond, Carolyn (1995). «Un espejo trizado: la fragmentada unidad de la obra ayaliana», en Manuel Ángel Vázquez Medel (ed.), El universo plural de Francisco Ayala. Sevilla: Alfar, pp. 23-30

Richmond, Carolyn (1998a). «“¿Para qué, entonces, afanarse en vano?”: el acto de escribir en la obra de Francisco Ayala», en Manuel Ángel Vázquez Medel (ed.), Francisco Ayala: el escritor en su siglo. Sevilla: Alfar, pp. 11-27.

Richmond, Carolyn (1998b). «De mitos y metamorfosis: las constantes vanguardistas en la obra narrativa de Francisco Ayala», en Manuel Ángel Vázquez Medel (ed.), Francisco Ayala y las vanguardias. Sevilla: Alfar, pp. 15-31

Romera Castillo, José (1992). «La memoria (auto)crítica del escritor incipiente Francisco Ayala», en Antonio Sánchez Trigueros y Antonio Chicharro (eds.), Francisco Ayala, teórico y crítico literario. Granada: Diputación de Granada, pp. 67-82.

Salaün, Serge (1998a). «Las vanguardias políticas: la cuestión estética», en Javier Pérez Bazo (ed.), La vanguardia en España. Arte y literatura. París: CRIC \& OPHRYS, pp. 209-225. 
Salaün, Serge (1998b). «Vanguardias estéticas en España», en Harald Wentzlaff-Eggebert (coord.), Nuevos caminos en la investigación de los años 20 en España. Tubinga: Max Niemeyer Verlag, pp. 37-46.

Senabre, Ricardo (2001). «La prosa ensayística de Francisco Ayala», en Antonio Sánchez Trigueros y Manuel Ángel Vázquez Medel (eds.), Francisco Ayala, escritor universal. Sevilla: Alfar, pp. 13-22.

Senabre, Ricardo (2006). «La crítica literaria de Francisco Ayala», en Susana Martínez-Garrido (coord.), Francisco Ayala. El escritor en su siglo. Madrid: Sociedad Estatal de Conmemoraciones Culturales, pp. 359-368.

Sobejano, Gonzalo (2012). Lecturas de Francisco Ayala. Granada: Fundación Francisco Ayala - Universidad de Granada.

Soldevila Durante, Ignacio (1992). «La contribución de Francisco Ayala al método histórico de las generaciones», Anthropos. 139, pp. 41-47.

Soria Olmedo, Andrés (2006). «Francisco Ayala y la generación del Veintisiete», en Luis García Montero (ed.), Francisco Ayala. De mis pasos en la tierra. Málaga: Junta de Andalucía, pp. 193-216.

Villanueva, Darío (1992). «La fenomenología literaria de Francisco Ayala», en Antonio Sánchez Trigueros y Antonio Chicharro (eds.), Francisco Ayala, teórico y crítico literario. Granada: Diputación de Granada, pp. 167-177.

Viñas Piquer, David (2000). «Hacia una ética de la escritura vanguardista: a propósito de Francisco Ayala», Anuari de Filologia. XXII, 10, pp. 117-128.

Viñas Piquer, David (2004). «Francisco Ayala o la teoría literaria en "román paladino"», en Antonio Sánchez Trigueros y Manuel Ángel Vázquez Medel (eds.), El tiempo y yo. Encuentro con Francisco Ayala y su obra. Sevilla: Alfar, pp. 43-51.

Fecha de recepción: 23 de septiembre de 2016.

Fecha de aceptación: 27 de enero de 2017. 